\title{
Movements through a fish ladder: temporal patterns and motivations to move upstream
}

\author{
Carlos Sérgio Agostinho, Celiana Ribeiro Pereira, Rafael José de Oliveira, \\ Iriene Siqueira Freitas and Elineide Eugênio Marques
}

Fish passages are constructed with the aim of reestablishing connectivity between critical habitats, in order to sustain those species that move over a large area during their lives. The upstream movements of most of the known migratory species are made for purposes of reproduction (adults) or dispersal (juveniles). The present study was conducted at the ladder constructed at Lajeado Dam (Luis Eduardo Magalhães Hydroelectric Power), on the Tocantins River. The objective was to assess whether there is a temporal pattern in the abundance of fish below the dam and in the ladder, that correlates with their breeding seasons. Additionally, it was examined whether reproduction is the predominant motivation of the shoals of fish that ascend the ladder. Samples were taken monthly from November, 2002 through October, 2003, downriver from the dam with gillnets, and in the resting pools of the fish ladder with cast nets. The analysis of seasonality in the aggregation of the shoals was based on the temporal variations in abundance and species richness. The possibility of a reproductive motivation for ascending the ladder was inferred from the frequency of the stages of gonadal development. However, during the entire study period we observed a high frequency of individuals with gonads in the pre-vitellogenic stage for all analyzed species, both downriver from the dam (97\%) and in the fish ladder (98\%). These findings suggest that there was no reproductive motivation for the aggregation of the fish downstream and for their entry into the ladder. On the other hand, the dominance of these stages downriver suggests that the spawning habitats are distant, and that the upstream movements occur for other reasons such as dispersal and search for more appropriate habitats for feeding and growth. The entrance into the ladder resulted more from rheophilic behavior, which is more pronounced in migratory species, than from an endogenous motivation linked to reproductive migration.

Os mecanismos de transposição de peixes em barragens visam restabelecer a conectividade entre habitats críticos à manutenção para as espécies que tenham uma ampla área de vida. Os movimentos ascendentes da maioria das espécies migradoras conhecidas são realizados por motivação reprodutiva (adultos) ou dispersiva (juvenis). Neste contexto, o presente estudo tem como objetivo avaliar se existe um padrão temporal na abundância de peixes a jusante da barragem e na escada da UHE Lajeado (UHE Luis Eduardo Magalhães, rio Tocantins) que segue a sazonalidade reprodutiva. Adicionalmente, busca avaliar se reprodução é a motivação predominante dos cardumes que ascendem a escada. Para isto, as amostragens foram realizadas mensalmente de novembro de 2002 a outubro de 2003 a jusante da barragem, com o uso de redes de espera, e nos tanques de descanso da escada, com tarrafas. A análise da sazonalidade na agregação dos cardumes foi baseada nas variações temporais de abundância e riqueza de espécies, enquanto a motivação reprodutiva para a ascensão foi inferida a partir da freqüência dos estádios de maturação gonadal. Entretanto, durante todo o período foi constatada uma elevada freqüência de indivíduos com gônadas em fase pré-vitelogênica em todas as espécies analisadas, tanto a jusante da barragem (97\%) como na escada (98\%), sugerindo a inexistência de motivação reprodutiva para a agregação dos peixes a jusante e seus ingressos na escada. Por outro lado, o fato destes estádios dominarem as capturas também a jusante sugere que os locais de desova estão distantes, e que os deslocamentos ascendentes ocorrem por outras razões, como dispersão natural e busca de habitats mais apropriados para alimentação e crescimento. Assim, o ingresso na escada decorreu mais do comportamento reofílico, exacerbado nas espécies migradoras, que de uma motivação endógena ligada à migração reprodutiva.

Key words: Fish migration, Fish conservation, Biodiversity, Reservoir, Seasonality.

Núcleo de Estudos Ambientais (Neamb), Universidade Federal do Tocantins, Campus de Porto Nacional, Rua 3, Quadra 17, Jardim dos Ipês, 77500-000 Porto Nacional, TO, Brazil. agostinhocs@uft.edu.br 


\section{Introduction}

The Neotropical fish fauna includes a staggering variety of migratory species, and their life histories are incredibly diverse (Carolsfeld et al., 2003). Individuals that move over long distances certainly increase fitness, contributing for the abundance and long-term existence of their population. Redistribution of part or all of the population through time and space can have the advantage of increasing growth rate, decreasing mortality rate and increasing natality rate (Barthem \& Goulding, 1997).

In spite of the profusion of life forms, and their broad distributions, all of them are now confronting a common dilemma: the increasing number of impoundments, which obstruct their access routes to areas crucial to their life cycle, which are located in different parts of their home range and which are often separated by hundreds or even thousands of kilometers (Barthem et al., 1991; Barthem \& Goulding, 1997; Agostinho et al., 2004a). These interruptions of migratory routes are probably the main factor that now affects the abundance of migratory fishes (Bayley \& Petrere Jr., 1989; Ribeiro et al., 1995; Northcote, 1998; Agostinho et al., 2005).

Fish passes are constructed with the objective of mitigating these impacts, reestablishing connectivity between habitats critical to the maintenance of the fishery stocks and to the conservation of species diversity in hydrographic basins (Agostinho et al., 2002). Thus, although the construction of these facilities is generally decided upon for diffuse objectives, it is expected that they would serve primarily to allow these species to reestablish access to the habitats where they spawn, undergo the first stages of their development, and feed.

In view of the motivations for reproduction or for dispersal (juveniles) of the upstream movements of the majority of known migratory species, it is expected that the ladders will promote the passage of fishes with this strategy, and that the fish will accumulate seasonally below the dam. It is also expected that fishes that aggregate downriver from the dam or that use the ladder for ascending have initiated preparation of the gonads, as reported by Godoy (1967) for shoals of Prochilodus in reproductive migration and by Agostinho et al. (1993) for the river stretches below the Itaipu Dam.

Temporal variations in the migration rate of fish in rivers (Godoy, 1959, 1967, 1975; Bonetto \& Pignalberi, 1964; Bonetto et al., 1971; Petrere Jr., 1985; Quirós, 1988; Agostinho et al., 1993) and in fish ladders (Malmqvist, 1980; Baras \& Cherry, 1990; Mallen-Cooper, 1999), and the accumulation of migrating fish immediately downstream from the barrier to migration are well documented (Mallen-Cooper, 1999; Taylor et al., 2001; Gehrke et al., 2002, among many others). However, studies of the motivations that lead neotropical species to ascend passage mechanisms are rare (Capeleti \& Petrere Jr., 2006; Pompeu \& Martinez, 2006).

The present study sought, through analysis of the temporal variations in abundance and species richness and of the degree of gonadal maturation of the fish, to answer two basic questions: (i) Is there a temporal pattern in the aggregation of fish below the dam and in their entry into the fish ladder at Lajeado Dam? (ii) Is reproduction the predominant motivation of the shoals of fish that ascend the ladder?

\section{Materials and Methods}

\section{Study area and sampling locales}

Lajeado Dam (L. E. Magalhães Hydroelectric Power) is the first dam for hydroelectric purposes in operation on the Tocantins River upstream from Tucuruí, the sixth in the series of 12 plants included in the Electrical Sector Ten-Year Plan (Plano Decenal do Setor Elétrico; ANA/CDOC, 2005), and the fourth to begin operating on this river. This dam was only the first to be provided with a fish-passage mechanism.

Construction of Lajeado Dam, located in the transition between the Middle and the Upper Tocantins River (Paiva, 1982) in the municipality of Miracema do Tocantins (48'22'17' 'S; 945'26"'W), was completed in October, 2001. Filling of the reservoir was completed in February, 2002. The reservoir occupies an area of $630 \mathrm{~km}^{2}$ and is about $172 \mathrm{~km}$ long, with a mean depth of $8.8 \mathrm{~m}$ and up to $35 \mathrm{~m}$ deep near the dam; the mean water residence time is 24 days and the mean surface velocity is $0.083 \mathrm{~m} . \mathrm{s}^{-1}$. The reservoir is inserted between two river stretches that are still lotic: about $140 \mathrm{~km}$ to Peixe Angical Dam upriver, and $880 \mathrm{~km}$ to the beginning of Tucuruí Reservoir downriver. However, planned hydroelectric plants for the basin, if carried out according to the present plan (ANA/CDOC, 2005) will eliminate almost all lotic sections above and below this reservoir.

The fish ladder constructed at Lajeado Dam, similar to another now functioning at the Peixe Angical Hydroelectric Power, is of the weir and orifice type, $874 \mathrm{~m}$ long, $5 \mathrm{~m}$ wide and with a $5 \%$ slope, for a gain in elevation of $36.8 \mathrm{~m}$. It is located left of and parallel to the tailrace, and has 92 step-tanks with openings at the surface $(0.5 \times 1.0 \mathrm{~m})$ and bottom $(0.8 \times 0.8 \mathrm{~m})$, in addition to five still-water resting pools (the first pool is $14.4 \times 17.0 \mathrm{~m}$, and the others are $10 \times 10 \mathrm{~m}$ ). A detailed description of the ladder is given by Agostinho et al. (2007b) in this issue. During the studied period, the discharge was maintained at about $3.3 \mathrm{~m}^{3} \cdot \mathrm{s}^{-1}$, which corresponds to a maximum velocity of $2.3 \mathrm{~m} . \mathrm{s}^{-1}$ at the bottom openings of the step-tanks.

The stretch sampled downriver from Lajeado Dam was located about one kilometer below it, near the attraction channel of the ladder. In this stretch, the Tocantins River is about $400 \mathrm{~m}$ wide and has a mean depth of $20 \mathrm{~m}$, with a rocky substrate and sandy deposits in backwaters. The hydrological regime in this stretch is markedly affected by the power plant operation.

\section{Sampling and data analysis}

Fish samplings were carried out in the stretch immediately downstream from Lajeado Dam and in its attached fish ladder, during the period from November, 2002 through October, 2003. In the downriver stretch, samples were taken with gillnets of different mesh sizes ( 2.4 to $16 \mathrm{~cm}$ between opposite knots), set out for one 24-hour cycle each month, and checked at 8:00, 16:00 and 22:00 hours. In the ladder, catches 
were made biweekly in the five resting pools, using cast nets with mesh size of $4.0 \mathrm{~cm}$ between opposite knots and a perimeter of $15 \mathrm{~m}$. These cast nets were operated in a standardized manner, at 12:00, 18:00, 00:00 and 06:00 hours, always beginning in the lowest pool (pool 1) and at 12:00 hours. In all the collecting periods, individuals caught were returned to the same pool after sampling was completed, except at 06:00 hours. These individuals, along with those collected downriver from the dam were identified, measured $(\mathrm{cm})$ and their sex and stage of gonadal development were identified macroscopically.

The species captured were classified according to their reproductive strategy into (i) long-distance migrants (MLD) and (ii) sedentary/short-distance migrants (NMLD), based on literature data (Vazzoler \& Menezes, 1992; Vazzoler, 1996; Carolsfeld et al., 2003; Agostinho et al., 2004b).

The abundance of individuals was indexed by the catch per unit effort (CPUE), and expressed as the number of individuals caught per $1000 \mathrm{~m}^{-2}$ gillnet. 24 hours ${ }^{-1}$, for the samples taken downriver, and as the number of individuals caught in 100 casts, for the samples taken in the ladder.

Identification of the gonadal development stages was based on macroscopic characteristics such as volume, vascular irrigation, color, turgidity, and visibility of oocytes (Vazzoler, 1996). The stages were grouped into immature (IMT), reproducing (RPD; mature, ripe and partially spawned) and non-reproducing (NRPD; resting and spent).

The seasonality of fish aggregation below the dam and inside the fish ladder was evaluated using the monthly distribution of richness and abundance of migratory and non-migratory individuals. Seasonality of the arrival of specific shoals in the ladder was analyzed based on the relative abundance (\% CPUE of the total catch, of each species in the period) per species, considering only those species with catches above 20 individuals. The hydrological periods considered were: flooding (October through December), flooded (January through March), drying (April through June) and drought (July through September).

The frequency of gonad maturation stages and the size composition of the species that ascended the fish ladder were used to infer if the reasons for the movements (reproductive or juvenile dispersion, or both). The reproductive activity downriver and in the ladder was evaluated for each species, based on the relative abundance of individuals (\% CPUE of the total catch) in the different stages of gonadal development. The proportions among size classes (small, medium and large) for the migratory species were compared using the $\chi^{2}$ test. The size classes were defined based on the range of standard lengths of the captured fish species.

\section{Results}

\section{Seasonality in the occurrence and abundance of fish}

High abundances of individuals and species richness, downriver from the dam and in the fish ladder, were recorded from December through May (Fig. 1). There was marked seasonality in both abundance and species richness, both downriver and in the fish ladder. Species richness in the ladder showed a lesser degree of seasonality, which resulted mainly from the low variability in the number of migratory species (Fig. 1).

Migratory individuals were more abundant than non-migratory ones in the ladder during the entire sampling period, except in May. The peak of abundance recorded in February in the fish ladder corresponds principally to the catch of Oxydoras niger and Psectrogaster amazonica, which represented $83.0 \%$ of the total catch in that month. On the other hand, downriver the non-migratory fished were more abundant than the migrants, except in May, when an inverse tendency were observed (Fig. 1).

Some species were recorded in the ladder during most of the year. Prominent among these were the migrants Rhaphiodon vulpinus, Oxydoras niger, Pimelodus blochii, Prochilodus nigricans, Hydrolycus armatus and Myleus torquatus, and non-migrators such as Myleus setiger, Serrasalmus rhombeus, Plagioscion squamosissimus, Panaque nigrolineatus and Hypostomus sp. 9 (Table 1).

Species such as Psectrogaster amazonica, Semaprochilodus brama, Rhaphiodon vulpinus and Oxydoras niger were present in the ladder in high abundance for one or two months during January through April, although a few individuals of the latter two species were recorded in at least 10 of the 12 months of the study (Table 1).

Although several species were recorded in the ladder during a large part of the year, their peaks of abundance occurred in different periods, even among the migratory species. Prochilodus nigricans, for example, showed abundance peaks at the end of the dry season and during the flooding stage, and Myleus torquatus during flooding; whereas Pseudoplatystoma fasciatum and Brycon falcatus were most abundant at the end of the drying season and the beginning of the drought (Table 1).

\section{Reproductive stage of the species}

Analysis of the frequency of the stages of gonadal maturation during a reproductive cycle revealed that the great majority of the adults analyzed showed no evidence of reproductive activity, both downriver (77.8\%) and in the ladder (90.5\%). Immature individuals (= juveniles) comprised $7.8 \%$ of those caught in the ladder and $19.1 \%$ downriver. Individuals ready to reproduce comprised only $2.9 \%$ and $1.8 \%$ of those in the downriver stretch and the ladder, respectively (Fig. 2).

Comparison of the proportions among the size classes of the migratory individuals that showed distinct peaks in abundance in the ladder revealed significant differences for Oxydoras niger (January-February; $\chi^{2}=20.37 ; \mathrm{df}=2$ and $\mathrm{p}=$ 0.000 ), Prochilodus nigricans (December-September; $\chi^{2}=$ 8.44; $\mathrm{df}=2$ and $\mathrm{p}=0.015)$ and Pseudoplatystoma fasciatum (April-July; $\chi^{2}=8.44 ; \mathrm{df}=2$ and $\mathrm{p}=0.015$ ). For $O$. niger, the initial shoal was composed predominantly of smaller individuals, in contrast to the second shoal. For P. nigricans and $P$. fasciatum, the first shoals to ascend the ladder were composed mainly of larger individuals. 


\section{Discussion}
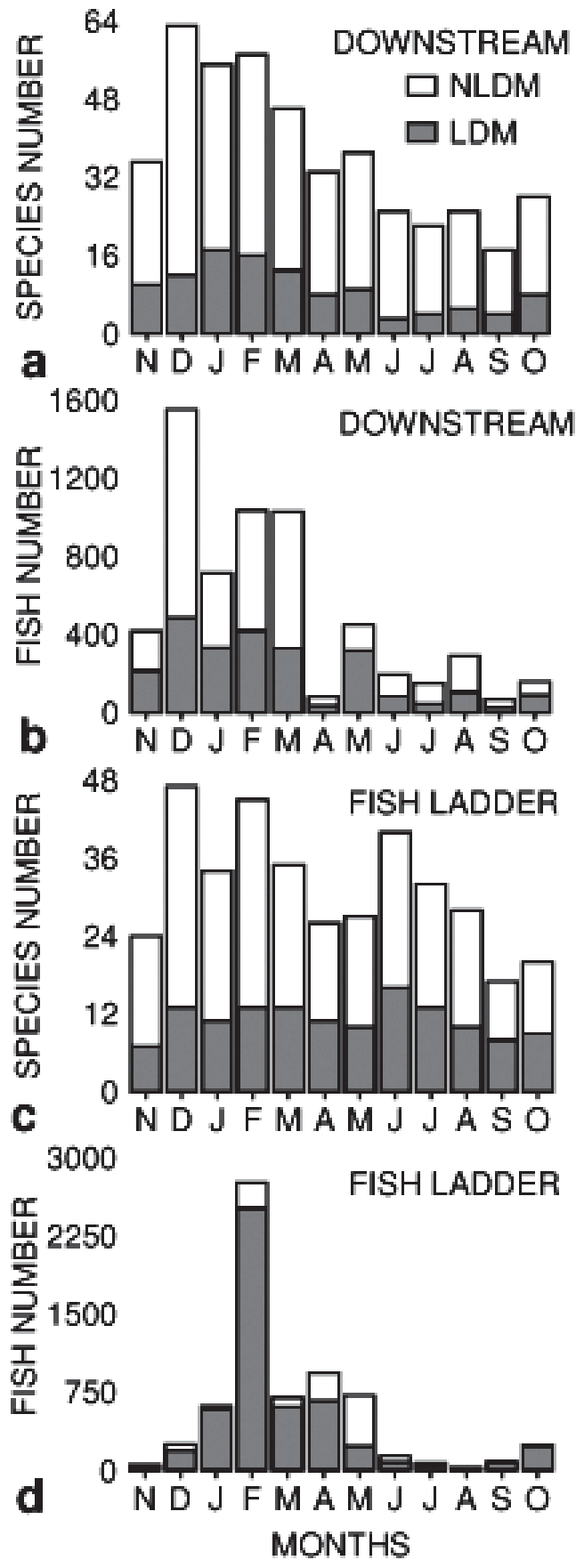

Fig. 1. Number of species and abundance of individuals downriver ( $\mathrm{a}$ and $\mathrm{b}$; fish. $1000 \mathrm{~m}^{-2}$ gillnet. 24 hours $^{-1}$ ) and in the ladder (c and d; fish. 100 casts $^{-1}$ ), from November, 2002 through October, 2003, according to reproductive strategy $(\mathrm{MLD}=$ long-distance migrants ; NMLD = sedentary/short-distance migrants), at Lajeado Dam.
In tropical regions, where temperature variations are little pronounced, the seasonality of water levels assumes a preponderant role affecting the movements of shoals of fish (Godoy, 1975; Agostinho \& Zalewski, 1995; Lowe-McConnell, 1999; Vazzoler, 1996). When water levels are rising, shoals in reproductive migration move upstream in search of spawning habitats; whereas when the waters are retreating to the main river channel, juveniles that passed their first months of life in flooded environments return to the river channel, where they disperse (Agostinho et al., 2004b). The concentrations of fish downriver from Lajeado Dam and their ascent of the ladder, which are strongly seasonal, are reflections of these population movements.

The majority of the individuals at Lajeado Dam were caught in the season of high water (December through April) and the beginning of the dry season (May). Other studies have also reported the synchrony between water levels and
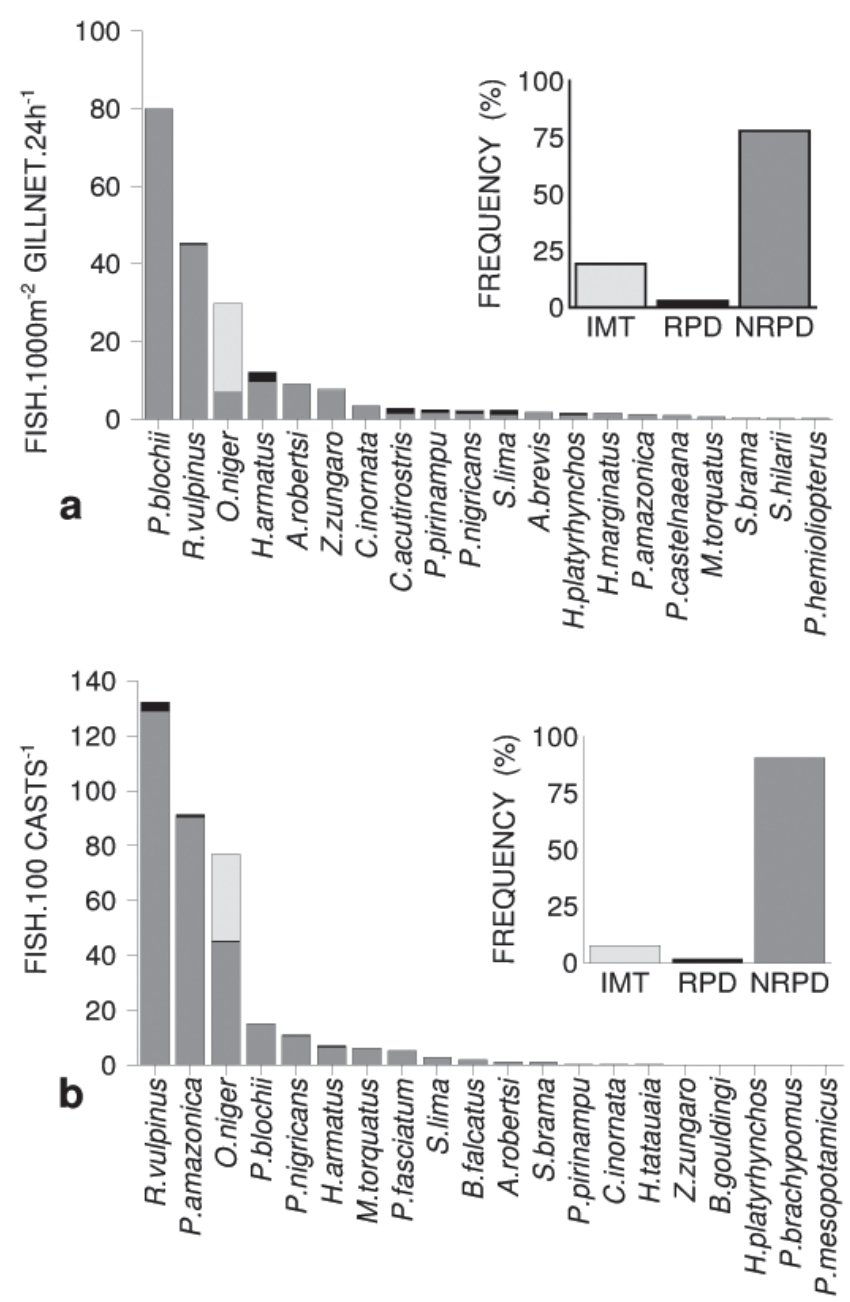

Fig. 2. Frequency of gonadal maturation stages (\%, smaller panels) and abundance of migratory species (females) according to gonadal maturation stages downriver (a) and in the ladder (b) at Lajeado Dam. IMT = immature individuals; $\mathrm{RPD}=$ reproducing; and $\mathrm{NRPD}=$ non-reproducing. 
Table 1. Number $(\mathrm{N})$ and abundance of migratory and non-migratory fish species by month and phase of the hydrological cycle. Only species present in the ladder with a number of individuals greater than 20 were included. The percentage of the catch per unit of effort, in number, is represented by: $-=<10 \% ;+=10$ to $15 \% ;++=15$ to $20 \%$; $+++=20$ to $25 \%$ and $++++=>25 \%$ Empty cell $=$ no catch.

\begin{tabular}{|c|c|c|c|c|c|c|c|c|c|c|c|c|c|}
\hline \multirow[b]{2}{*}{ SPECIES } & \multirow[b]{2}{*}{$\mathrm{N}$} & \multicolumn{2}{|c|}{ FLOODING } & \multicolumn{3}{|c|}{ FLOOD } & \multicolumn{3}{|c|}{ DRYING } & \multicolumn{3}{|c|}{ DROUGHT } & \multirow{2}{*}{$\begin{array}{c}\text { FLOODING } \\
\text { OCT }\end{array}$} \\
\hline & & NOV & DEC & JAN & FEB & MAR & APR & MAY & JUN & JUL & AUG & SEP & \\
\hline Long distance migratory & & & & & & & & & & & & & \\
\hline Rhaphiodon vulpinus & 3153 & & - & - & + & + & ++++ & - & - & - & & - & + \\
\hline Psectrogaster amazonica & 2176 & & & & $++1+$ & - & 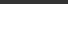 & & & & & & \\
\hline Oxydoras niger & 1832 & - & - & t++ & t+t+ & + & - & - & - & - & - & - & - \\
\hline Pimelodus blochii & 362 & & & & ++++ & - & - & ++++ & - & - & - & & - \\
\hline Prochilodus nigricans & 261 & - & +++ & - & - & - & & - & - & - & - & $++t+$ & \\
\hline Hydrolycus armatus & 166 & - & + & ++ & ++ & - & - & - & - & - & - & - & - \\
\hline Myleus torquatus & 146 & - & 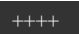 & + & + & ++ & - & - & - & - & & & \\
\hline Pseudoplatystoma fasciatum & 124 & . & - & & & & ++ & - & t+t+ & ++++ & - & & \\
\hline Sorubim lima & 69 & + & - & & ++ & + & & ++++ & + & - & & & \\
\hline Brycon falcatus & 44 & & - & & & & & h+t & ++++ & ++ & ++ & & - \\
\hline Argonectes robertsi & 28 & & - & & & & & & ++ & ++ & ++ & + & t+t+ \\
\hline Semaprochilodus brama & 22 & & & ++4 & ++++ & & + & - & & & & & \\
\hline Non-long distance migratory & & & & & & & & & & & & & \\
\hline Auchenipterus nuchalis & 1258 & & & & - & - & $+4++$ & th+t & - & & & & \\
\hline Triportheus trifurcatus & 373 & & - & - & $++t+$ & $+1++$ & - & - & & & & & \\
\hline Myleus setiger & 164 & - & ++++ & - & + & - & - & - & + & + & - & - & - \\
\hline Anchoviella carrikeri & 84 & + & + & & & $++1+$ & - & & - & & & & - \\
\hline Serrasalmus rhombeus & 69 & & - & ++ & 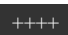 & + & + & + & + & - & & & - \\
\hline Plagioscion squamosissimus & 67 & - & ++ & - & + & - & - & + & + & ++ & & & \\
\hline Panaque nigrolineatus & 62 & & - & - & + & + & ++++ & - & + & - & - & & - \\
\hline Brycon pesu & 44 & - & & & & & & & $+4++$ & +4+ & ++ & $++4+$ & \\
\hline Hypostomus sp9 & 40 & . & - & + & & + & - & ++++ & - & + & + & & \\
\hline Pachyurus junki & 40 & & & & & & & h++ & ++++ & & & & \\
\hline Hemiodus microlepis & 32 & & ++++ & & t+t+ & & & & +++ & & & & \\
\hline Myleus spB & 28 & & - & + & & & & & $+4++$ & + & +h+ & & \\
\hline
\end{tabular}

the flow of fish through fish-translocation mechanisms in the neotropical region. In the ladder at Igarapava Dam, fish abundance was higher during the local rainy season (Vono et al., 2004). In the Yaceretá elevator on the Paraná River, fish were more abundant during the high-water period (Oldani \& Baigún, 2002). The fall in water level of the Mucuri River downstream from the Santa Clara Dam was the principal explanatory variable for the abundance of individual fish translocated in their mechanism (Pompeu \& Martinez, 2006). Inter-annual variations in water level can alter the period when the shoals arrive (Capeleti \& Petrere Jr., 2006), and the occasional absence of flood stages, either occurring naturally or artificially created, can frustrate these movements and, hence, spawning (Agostinho et al., 2004b).

In spite of the seasonality in abundance and species richness downriver and in the ladder, the migratory species showed no single temporal pattern in ladder use at Lajeado Dam. Rhaphiodon vulpinus, Psectrogaster amazonica, Oxydoras niger, Hydrolycus armatus, Myleus torquatus and Semaprochilodus brama used the ladder predominantly or exclusively during the flooded period. Pseudoplatystoma fasciatum, Brycon falcatus and Sorubim lima were most abundant in the ladder during the drought period. Pimelodus blochii, Prochilodus nigricans and Argonectes robertsi used the ladder in both periods. The non-migratory fishes showed a similar lack of any single pattern. This leads us to suppose that the motivation for the use of fish ladders varies among species and within the same species.
Northcote (1998) reports that the motivation for the migratory behavior of riverine fishes is related to a search for habitats for reproduction, growth and feeding. The presence of species of the genera Leporinus, Prochilodus and Brycon in the elevator of the Santa Clara Hydroelectric Power was related to reproductive migration; whereas the occurrence of centropomids and mugilids, which do not spawn in fresh water, was associated with feeding movements (Pompeu \& Martinez, 2006). The high frequency of migratory individuals in pre-vitellogenic stages in the Lajeado ladder during the entire year indicates that the majority of species are probably not carrying out a reproductive migration. It would be expected that during the flooded period, the individual fish would have gonads at least in the initial stage of vitellogenesis, because shoals in the process of reproductive migration contain mostly maturing individuals (Godoy, 1967).

The shoals of the same species that arrive at the fish ladders at different times, may have different motivations to ascend them. Capeleti \& Petrere Jr. (2006) reported that the reproductive motivation, evaluated from the stage of gonadal maturation, was restricted to those fish that arrived at Cachoeira de Emas in the beginning of the flood season (October), in contrast to those that arrived later (March and April).

Although the shoals moving upriver are generally composed of heterogeneous age groups, as observed by Godoy (1959) for Prochilodus lineatus, the predominance of juveniles among those that reach the ladders can result in dis- 
persal behaviors. Under natural conditions, these movements assure a wider distribution for the population, contributing to the increase in fitness of the migrants. They are predominantly ascending movements, probably toward the tributaries where they hatched (Ribeiro, 1983), and help to counterbalance the passive transport of eggs and larvae downriver (Lowe-McConnell, 1999). This phenomenon, known as the "lufada" (flurry) in the Pantanal, has also been described for the Paraná River (Agostinho et al., 2007a), and is most evident during the drying period and after exceptional flooding. Thus, it is possible that the delayed shoals of Prochilodus nigricans and Pseudoplatystoma fasciatum, at the end of the drying and during the drought seasons, comprised predominantly smaller-sized individuals, reached the ladder in the course of their dispersal movements to the upstream stretches. Differences in size composition between shoals of Prochilodus that migrate for reproduction and for dispersal were reported by Bayley (1973) for the Pilcomayo River (Paraná-Paraguay basin) and by Capeleti \& Petrere Jr. (2006) for those that arrive at Cachoeira das Emas. Nevertheless, the predominance of juveniles in the catches of Oxydoras niger at the beginning of the rainy season, when the reproductive activity of the species also begins (Elineide E. Marques, personal communication), reveals a different mechanism which is not linked to the retreat of the waters in the drying stage.

The high density of prey in the ladder, the environmental homogeneity and exhausted state of the prey during their ascent of the ladder, guarantee favorable feeding conditions for the piscivorous species, and this could explain why migratory predators (Rhaphiodon vulpinus, Pseudoplatystoma fasciatum and Hydrolycus armatus) and non-migratory predators (Serrasalmus rhombeus and Plagioscion squamosissimus) remain in the ladder during most of the year. In this respect, the ladder resembles terrestrial corridors that link forest fragments, where individuals are subject to intense predation pressure.

The temporal patterns observed in this study clearly revealed the existence of seasonality in species richness and in the concentrations of fish in the stretch downriver from Lajeado Dam, in both migratory and non-migratory species. Although this seasonality was also observed in the ladder, the presence of resident species attenuated the seasonal fluctuations in species number, especially of migrants, for which the monthly fluctuations in their abundance are accentuated. On the other hand, the high frequency of individuals in previtellogenic stages suggests that reproductive migration is not the principal motivation for the species to ascend the ladder. Contrariwise, the dominance of these stages in the catches downriver may indicate that the spawning places are distant. Therefore, it can be supposed that the ascending movements stem from natural dispersal and the search for more appropriate habitats for feeding and growth. The ascension of the ladder is motivated by the rheophilic nature of the majority of species, especially the migrants.

\section{Acknowledgments}

We are grateful to our colleagues of the Núcleo de Estudos Ambientais (Neamb), Universidade Federal do Tocantins (UFT), for their assistance in the field and laboratory work. We also thank Investco S.A. for financial and Neamb/UFT for logistical support.

\section{Literature Cited}

Agostinho, A. A., L. C. Gomes, D. R. Fernandes \& H. I. Suzuki. 2002. Efficiency of fish ladders for Neotropical ichthyofauna. River Research an Application, 18(3): 299-306.

Agostinho, A. A., L. C. Gomes \& J. D. Latini. 2004a. Fisheries management in Brazilian reservoirs: lessons from/for South America. Interciencia, 29(6): 334-338.

Agostinho, A. A., L. C. Gomes \& F. M. Pelicice. 2007a. Ecologia e manejo de recursos pesqueiros em reservatórios do Brasil. Maringá, EDUEM, 460p.

Agostinho, A. A., L. C. Gomes, S. Veríssimo \& E. K. Okada. 2004b. Flood regime, dam regulation and fish in the upper Paraná River: effects on assemblage attributes, reproduction and recruitment. Reviews in Fish Biology and Fisheries, 14(1): 11-19.

Agostinho, A. A., V. P. Mendes, H. I. Suzuki \& C. Canzi. 1993. Avaliação da atividade reprodutiva da comunidade de peixes dos primeiros quilômetros a jusante do reservatório de Itaipu. Revista UNIMAR, Maringá, 15(Suplemento): 175-189.

Agostinho, A. A., S. M. Thomaz \& L. C. Gomes. 2005. Conservation of the biodiversity of Brazil's inland waters. Conservation Biology, 19(3): 646-652.

Agostinho, A. A. \& M. Zalewski. 1995. The dependence of fish community structure and dynamics on floodplain and riparian ecotone zone in Paraná River, Brazil. Hydrobiologia, 303: 141148.

Agostinho, C. S., A. A. Agostinho, F. M. Pelicice, D. A. A. Almeida \& E. E. Marques. 2007b. Selectivity of fish ladders: a bottleneck in Neotropical fish movement. Neotropical Ichthyology, 5(2): 205-213.

ANA-CDOC. 2005. Aproveitamento do potencial hidráulico para geração de energia. Caderno de Recursos Hídricos. Brasília, ANA/ CDOC, 93p.

Baras, E. \& B. Cherry. 1990. Seasonal activities of female barbel Barbus barbus (L) in the River Ourthe (Southern Belgium), as revealed by radio tracking. Aquat. Living Resources, 3: 283 294.

Barthem, R. \& M. Goulding. 1997. The catfish connection: ecology, migration and conservation of Amazonian predators. New York, Columbia University Press, $144 p$.

Barthem, R. B., M. C. L. B. Ribeiro \& M. Petrere Jr. 1991. Life strategies of some long-distance migratory catfish in relation to hydroelectric dam in the Amazon basin. Biological Conservation, 55: 339-345

Bayley, P. B. 1973. Studies on the migratory characin, Prochilodus platensis Holmberg, 1889 (Pisces, Characoidei) in the River Pilcomayo, South America. Journal of Fish Biology, 5: 25-40.

Bayley, P. B. \& M. Petrere Jr. 1989. Amazon fisheries: Assessment methods, current status and management options. Canadian Special Publication of Fisheries and Aquatic Sciences, 106: 385398 
Bonetto, A. A. \& C. Pignalberi. 1964. Nuevos aportes al conocimiento de las migraciones de los peces en los ríos mesopotámicos de la Republica Argentina. Comunicación Instituto Nacional de Limnologia, Santo Tomé, 1: 1-14.

Bonetto, A. A., C. Pignalberi, E. Cordiviola de Yuan \& O. Oliveros. 1971. Informaciones complementarias sobre migraciones de peces en la cuenca del Plata. Physis, Buenos Aires, 30(81): 505520.

Capeleti, A. R. \& M. Petrere Jr. 2006. Migration of the curimbata Prochilodus lineatus (Valenciennes, 1836) (Pisces, Prochilodontidae) at the waterfall "Cachoeira de Emas" of the MogiGuaçu river - São Paulo, Brazil. Brazilian Journal of Biology, 66(2B): 651-659.

Carolsfeld, J., B. Harvey, C. Ross \& A. Baer. 2003. Migratory fishes of South America: biology, fisheries and conservation status. World Fisheries Trust, British Columbia, Canada, 380p.

Gehrke, P. C., D. M. Gilligan \& M. Barwick. 2002. Changes in fish communities of the Shoalhaven River 20 years after construction of Tallowa Dam, Australia. River Research and Aplications, 18: 265-286.

Godoy, M. P. 1959. Age, growth, sexual maturity, behavior, migration, tagging and transplantation of the curimbatá (Prochilodus scrofa, Steindachner, 1881) of the Mogi Guaçu river, São Paulo State, Brazil. Anais da Academia Brasileira de Ciências, São Paulo, 31: 447-477.

Godoy, M. P. 1967. Dez anos de observações sobre periodicidade migratória de peixes do rio Mogi Guaçu. Revista Brasileira de Biologia, 27: 1-12.

Godoy, M. P. 1975. Peixes da sub-ordem Characoidei - Bacia do rio Mogi-Guaçu. Piracicaba, Franciscana. 4v.

Lowe-McConnell, R. H. 1999. Estudos ecológicos de comunidades de peixes tropicais. São Paulo, Edusp, 535p.

Mallen-Cooper, M. 1999. Developing fishways for non-salmonid fishes: a case study from the Murray river in Australia. Pp. 173-195. In: Odeh, M. (Ed.). Innovatios in fish passage technology. Bethesda, American Fisheries Society, 224p.

Malmqvist, B. 1980. The spawning migration of the brook lamprey, Lampetra planeri Bloch, in a South Swedish stream. Journal of Fish Biology, 16(1): 105-114.
Northcote, T. G. 1998. Migratory behavior of fish and its significance to movement through riverine fish passage facilities. Pp. 3-18. In: Jungwirth, M., S. Schmutz \& S. Weiss (Eds.). Fish migration and fish bypasses. Oxford and London, Fish News Books, 438p.

Oldani, N. O. \& C. R. M. Baigún. 2002. Performance of a fishway system in a major South American dam on the Parana River (Argentina-Paraguay). River Research and Applications, 18(2): 171-183.

Paiva, M. P. 1982. Grandes Represas do Brasil. Brasília, Editerra, $304 \mathrm{p}$.

Petrere Jr., M. 1985. Migraciones de peces de agua dulce en America Latina: algunos comentarios. COPESCAL Documento Ocasional, Roma, 1:1-17.

Pompeu, P. dos S. \& C. B. Martinez. 2006. Temporal patterns of fish passage in Santa Clara Power Plant's fish lift, Murici River, east Brazil. Revista Brasileira de Zoologia, 23(2): 340-349.

Quirós, R. 1988. Structures assisting migrations of fish other than salmonids: Latin America. FAO-COPESCAL Technical Document, Rome, (5): 1-50.

Ribeiro, M. C. L. B. 1983. As migrações dos jaraquis (Pisces, Prochilodontidae) no rio Negro, Amazonas, Brasil. Dissertação de mestrado, Instituto Nacional de Pesquisas da Amazônia, Manaus. 192p.

Ribeiro, M. C. L. B., M. Petrere Jr. \& A. A. Juras. 1995. Ecological integrity and fisheries ecology of the Araguaia-Tocantins river basin, Brazil. Regulated Rivers: Research and Management, 10: 325-350.

Taylor, C. A., J. H. Knouft \& T. M. Hiland. 2001. Consequences of stream impoundment on fish communities in a small North American Drainage. Regulated Rivers: Research and Management, 17: 687-698.

Vazzoler, A. E. A. de M. 1996. Biologia da Reprodução de Peixes Teleósteos: Teoria e Prática. Maringá, EDUEM, 169p.

Vazzoler, A. E. A. de M. \& N. A. Menezes. 1992. Síntese de conhecimentos sobre o comportamento reprodutivo dos Characiformes da América do Sul (Teleostei, Ostariophysi). Revista Brasileira de Biologia, 52(4): 627-640.

Vono, V., P. M. Bizzotto, H. P. Godinho, A. L. Godinho \& B. Kynard. 2004. Fish passage at the Igarapava fish ladder, River Grande, Brazil. Pp. 1-5. In: Annals of the International Congress on the Biology of Fish Tropical. Hotel Resort. Manaus, American Fisheries Society. 